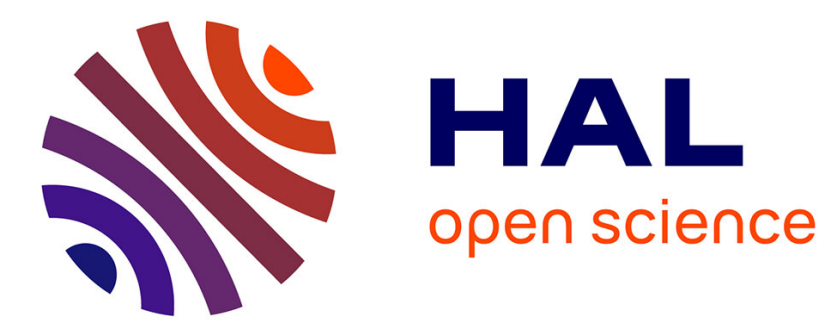

\title{
Hydrothermal Synthesis and Crystal Structure of Three-dimensional Supramolecular Zinc, Manganese Coordination Polymers
}

Zhi-Tao Wang, Valentin Valtchev, Qian-Rong Fang, Xiu-Mei Li, Ya-Ru Pan

\section{- To cite this version:}

Zhi-Tao Wang, Valentin Valtchev, Qian-Rong Fang, Xiu-Mei Li, Ya-Ru Pan. Hydrothermal Synthesis and Crystal Structure of Three-dimensional Supramolecular Zinc, Manganese Coordination Polymers. Inorganic and Nano-Metal Chemistry, 2019, 49 (2), pp.44-50. 10.1080/24701556.2019.1586724 . hal03039949

HAL Id: hal-03039949

https://hal-normandie-univ.archives-ouvertes.fr/hal-03039949

Submitted on 17 Dec 2020

HAL is a multi-disciplinary open access archive for the deposit and dissemination of scientific research documents, whether they are published or not. The documents may come from teaching and research institutions in France or abroad, or from public or private research centers.
L'archive ouverte pluridisciplinaire HAL, est destinée au dépôt et à la diffusion de documents scientifiques de niveau recherche, publiés ou non, émanant des établissements d'enseignement et de recherche français ou étrangers, des laboratoires publics ou privés. 


\section{Hydrothermal Synthesis and Crystal Structure of Three-dimensional Supramolecular Zinc, Manganese Coordination Polymers}

Zhi-Tao Wang ${ }^{\mathrm{a}} \cdot$ Valentin Valtchev ${ }^{\mathrm{b}} \cdot$ Qian-Rong Fang $^{\mathrm{b}} \cdot$ Xiu-Mei Li $\mathrm{Li}^{\mathrm{a}} \cdot$ Ya-Ru Pan ${ }^{\mathrm{a}}$

${ }^{a}$ Faculty of Chemistry, Tonghua Normal University, Tonghua 134002, People's Republic of China

b State Key Laboratory of Inorganic Synthesis and Preparative Chemistry, Jilin University, Changchun 130012, People's Republic of China

* Correspondence author: Prof. Xiu-Mei Li

E-mail: 619653104@qq.com

Telephone: +860435 3208077

Fax: +860435 3208079 


\begin{abstract}
Hydrothermal Synthesis and Crystal Structure of Three-dimensional Supramolecular Zinc, Manganese Coordination Polymers
\end{abstract}

Zhi-Tao Wang · Valentin Valtchev · Qian-Rong Fang $\cdot$ Xiu-Mei Li $\cdot$ Ya-Ru Pan

Two new complexes $\left[\mathrm{Zn}_{2}(\mathrm{pzdc})(\mathrm{L})_{2}\left(\mathrm{H}_{2} \mathrm{O}\right)\right]_{2 n} \cdot 2 \mathrm{nH}_{2} \mathrm{O} \quad$ (1) and $\quad\left[\mathrm{Mn}\left(\mu_{2}-\mathrm{O}\right)\left(\mathrm{H}_{2} \mathrm{O}\right)_{2}-\right.$ $(\mathrm{HL})]_{2 \mathrm{n}} \cdot 2 \mathrm{nNIPH}$ (2) $\left(\mathrm{H}_{2}\right.$ pzdc $=$ pyrazine-2,3-dicarboxylic acid, $\mathrm{HL}=3$-(2-Pyridyl $)$ pyrazole, $\mathrm{H}_{2} \mathrm{NIPH}=5$-nitroisophthalic acid) have been hydrothermally synthesized and structurally characterized by elemental analysis, IR spectrum, UV spectrum, TG, fluorescence spectrum and single-crystal X-ray diffraction. Complex $\mathbf{1}$ shows two-dimensional (2D) network, which was stabilized by $\mathrm{O}-\mathrm{H} \cdots \mathrm{O}, \mathrm{C}-\mathrm{H} \cdots \mathrm{O}$ hydrogen bonding and $\pi-\pi$ interactions and extended into 3D supramolecular architecture. Complex 2 is zero-dimensional structure, which was further extended into 3D supramolecular framework through $\mathrm{N}-\mathrm{H} \cdots \mathrm{O}, \mathrm{O}-\mathrm{H} \cdots \mathrm{O}, \mathrm{C}-\mathrm{H} \cdots \mathrm{O}$ hydrogen bonds and $\pi-\pi$ interactions.

Keywords hydrothermal synthesis $\cdot$ crystal structure $\cdot \mathrm{Zn}(\mathrm{II})$ complex $\cdot \mathrm{Mn}(\mathrm{II})$ complex 


\section{Introduction}

The design and synthesis of metal-organic coordination polymers relied on the selection of ligands and metal ions has become a very attractive research field. This is motivated not only by the intriguing structural diversity but also by the demand of applying functional materials into the fields of catalysis, porosity, magnetism, luminescence and nonlinear optics. ${ }^{[1-3]}$ In general, grids with various sizes and shapes can be synthesized by choosing suitable single metal ions and organic ligands such as carboxylates and N-donor groups. ${ }^{[4-6]}$ Self-assembly is a complex process, highly influenced by many factors, such as the coordination geometry of metal ions, the nature of organic ligands, solvent system, temperature, $\mathrm{pH}$ value of the solution, the ratio between metal salt and ligand, the templates and the counter anions. ${ }^{[7-14]}$ Except for these factors, other forces such as hydrogen-bonding, $\pi-\pi$ interactions, metal-metal interactions can also greatly influence the supramolecular topology and its dimensionality. ${ }^{[15-17]}$ Therefore, these considerations made us investigate new coordination structures with pyrazine-2,3-dicarboxylic acid $\left(\mathrm{H}_{2}\right.$ pzdc), 5-nitroisophthalic acid $\left(\mathrm{H}_{2} \mathrm{NIPH}\right)$ and chelating ligands. In this manuscript, we reported the syntheses, crystal structures, IR, UV, fluorescence, TG properties of two new complexes, namely, $\left[\mathrm{Zn}_{2}(\mathrm{pzdc})(\mathrm{L})_{2}\left(\mathrm{H}_{2} \mathrm{O}\right)\right]_{2 \mathrm{n}} \cdot 2 \mathrm{nH}_{2} \mathrm{O}(\mathbf{1})$ and $\left[\mathrm{Mn}\left(\mu_{2}-\mathrm{O}\right)\left(\mathrm{H}_{2} \mathrm{O}\right)_{2}(\mathrm{HL})\right]_{2 \mathrm{n}} \cdot 2 \mathrm{nNIPH}$ (2).

\section{Experimental Section}

\section{General procedures}


All solvents and chemicals were commercial reagents and used without further purification. Elemental analyses (carbon, hydrogen, and nitrogen) were performed with a Vario EL(III) Elemental Analyzer. IR spectrum(4000 400 $\mathrm{cm}^{-1}$ ) was measured from $\mathrm{KBr}$ pellet on a Nicolet 6700 FT-IR spectrometer. TG studies were performed on a Perkin-Elmer TGA7 analyzer. UV spectrum was obtained on a Shimzu UV-250 spectrometer in the 200 400 nm range. The fluorescent studies were carried out on a computer-controlled JY Fluoro-Max-3 spectrometer at room temperature. The crystal structure was determined by a Bruker D8 Venture diffractometer. Power X-ray diffraction (PXRD) patterns were obtained on Bruker D8 Advance X-ray diffractmeter with $\mathrm{Cu} K \alpha$ radiation $(\lambda=1.54056 \AA)$ at room temperature.

\section{Synthesis}

$\left[\mathrm{Zn}_{2}(\mathrm{pzdc})(\mathrm{L})_{2}\left(\mathrm{H}_{2} \mathrm{O}\right)\right]_{2 \mathrm{n}} \cdot 2 \mathrm{nH}_{2} \mathrm{O}(\mathbf{1}):$ A mixture of $\mathrm{H}_{2} \mathrm{pzdc}(0.068 \mathrm{~g}, 0.4 \mathrm{mmol}), \mathrm{HL}$ (0.028 g, $0.2 \mathrm{mmol}), \mathrm{Zn}(\mathrm{OAc})_{2} \cdot 2 \mathrm{H}_{2} \mathrm{O}(0.088 \mathrm{~g}, 0.4 \mathrm{mmol})$, and $18 \mathrm{~mL} \mathrm{H} \mathrm{H}_{2} \mathrm{O}$ was adjusted to the $\mathrm{pH} \approx 6.13$ with $0.5 \mathrm{~mol} \cdot \mathrm{L}^{-1} \mathrm{NaOH}$, sealed in a Teflon-lined stainless steel vessel, heated to $160{ }^{\circ} \mathrm{C}$ for five days, and followed by slow cooling (a descent rate of $10{ }^{\circ} \mathrm{C} / \mathrm{h}$ ) to room temperature. Pale yellow block crystals were obtained. Yield of 32\% (based on Zn). Anal. Calcd. For $\mathrm{C}_{44} \mathrm{H}_{32} \mathrm{~N}_{16} \mathrm{O}_{11} \mathrm{Zn}_{4}$ : C, 43.23; H, 2.64; N, 18.33. Found C, 42.97; H, 2.15; N, 17.89. IR $\left(\mathrm{cm}^{-1}\right)$ : 3286(w), 2989(w), 1752(m), 1637(m), 1605(m), 1567(w), 1473(w), 1434(w), 1375(m), 1357(m), 1255(w), 1159(w), 1118(w), 1060(w), 1013(m), 890(w), 783(w), 765(w), 636(w), 481(w).

$\left[\mathrm{Mn}\left(\mu_{2}-\mathrm{O}\right)\left(\mathrm{H}_{2} \mathrm{O}\right)_{2}(\mathrm{HL})\right]_{2 \mathrm{n}} \cdot 2 \mathrm{nNIPH}(2)$ : A mixture of $\mathrm{Mn}(\mathrm{OAc})_{2} \cdot 4 \mathrm{H}_{2} \mathrm{O}(0.10 \mathrm{~g}, 0.4$ mmol), $\mathrm{H}_{2} \mathrm{NIPH}(0.084 \mathrm{~g}, 0.4 \mathrm{mmol}), \mathrm{L}(0.058 \mathrm{~g}, 0.4 \mathrm{mmol})$, and $18 \mathrm{~mL} \mathrm{H} \mathrm{H}_{2} \mathrm{O}$ was placed 
in a Teflon reactor $(30 \mathrm{~mL})$ and the $\mathrm{pH}$ value was adjusted to about 7 with $0.5 \mathrm{~mol} \cdot \mathrm{L}^{-1}$ $\mathrm{NaOH}$ solution. Then the mixture was heated at $140{ }^{\circ} \mathrm{C}$ for 7 days. After cooling to room temperature at a rate of $10{ }^{\circ} \mathrm{C} / \mathrm{h}$, brown crystals of $\mathbf{1}$ were collected in $45 \%$ yield. Anal. Calcd. for $\mathrm{C}_{32} \mathrm{H}_{30} \mathrm{Mn}_{2} \mathrm{~N}_{8} \mathrm{O}_{18}(\%): \mathrm{C}, 41.57 ; \mathrm{H}, 3.27 ; \mathrm{N}, 12.12$. Found (\%): 41.36; H, 3.01; N, 11.98. IR (KBr, $\left.\mathrm{cm}^{-1}\right): 3413(\mathrm{~m}), 3102(\mathrm{w}), 1630(\mathrm{~s}), 1606(\mathrm{~s}), 1583(\mathrm{~m}), 1533(\mathrm{~m})$, 1495(w), 1443(w), 1334(s), 1101(w), 998(w), 788(w), 720(m), 537(w).

\section{X-ray crystallographic}

Single-crystal X-ray diffraction data for $\mathbf{1}$ and $\mathbf{2}$ were measured on a Bruker Smart Apex II CCD diffractometer with graphite-monochromated Mo $\mathrm{K} \alpha$ radiation $(\lambda=$ $0.71073 \AA$ ) at $293 \mathrm{~K}$. The structure was solved with the direct method of SHELXS-97 and refined with full-matrix least-squares techniques using the SHELXL-97 program. ${ }^{[18,}$ ${ }^{19]}$ Anisotropic thermal parameters were assigned to all non-hydrogen atoms. The hydrogen atoms were placed at the calculated positions and refined as riding atoms with isotropic displacement parameters. Crystallographic parameters and the data collection statistics for structure $\mathbf{1}$ and $\mathbf{2}$ are listed in Table 1. Selected bond lengths and bond angles are shown in Table 2. Further crystallographic parameters have been deposited with the Cambridge Crystallographic Data Centre (no. 1468826 (1), 1439401 (2); deposit@ccdc.cam.ac.uk or http://www.ccdc.cam.ac.uk/data_request/cif).

\section{Results and discussion}

\section{IR Spectrum}


Complex 1: Two bands at 1637 and $1357 \mathrm{~cm}^{-1}$ can be attributed to $\left(v(\mathrm{OCO})_{\text {assym }}\right)$ and $\left(\mathrm{v}(\mathrm{OCO})_{\text {sym }}\right),{ }^{[20]}$ respectively. The $\Delta v\left(v(\mathrm{OCO})_{\text {assym }}-v(\mathrm{OCO})_{\text {sym }}\right)$ is $280 \mathrm{~cm}^{-1}(>200)$, exhibiting the presence of monodentate linkage of carboxylates in the dianions. Therefore the carboxylates coordinate to the metal as monodentate ligands via the carboxylate groups. ${ }^{[21]}$ The absence of the characteristic bands at abound $1700 \mathrm{~cm}^{-1}$ in complex $\mathbf{1}$ were owing to the protonated carboxylic group indicates that the complete deprotonation of pzdc ligand upon reaction with Zn ions. ${ }^{[22]}$ Moreover, X-ray diffraction analysis further attributes the existence of monodentate coordination manners of the carboxylate groups and prence deprotonation of pzdc ligands.

Complex 2: Infrared spectroscopy of complex 2 shows the typical anti-symmetric (1606 $\left.\mathrm{cm}^{-1}\right)$ and symmetric $\left(1334 \mathrm{~cm}^{-1}\right)$ stretching bands of carboxylate groups. The absence of the characteristic band around $1700 \mathrm{~cm}^{-1}$ in complex 2 owing to the protonated carboxylic group indicates that the present deprotonation of NIPH ligand. Moreover, the strong and broad band centered at $3413 \mathrm{~cm}^{-1}$ for 2 is owing to the $\mathrm{H}-\mathrm{O}-\mathrm{H}$ stretching vibration of water molecule in the light of the known structure. ${ }^{[23]}$ 
Table 1. Crystallographic parameters and summary of data collection for $\mathbf{1}$ and $\mathbf{2}$

\begin{tabular}{|c|c|c|}
\hline Parameter & Complex 1 & Complex 2 \\
\hline Empirical formula & $\mathrm{C}_{44} \mathrm{H}_{32} \mathrm{~N}_{16} \mathrm{O}_{11} \mathrm{Zn}_{4}$ & $\mathrm{C}_{32} \mathrm{H}_{30} \mathrm{Mn}_{2} \mathrm{~N}_{8} \mathrm{O}_{18}$ \\
\hline $\mathrm{FW}(\mathrm{g} / \mathrm{mol})$ & 1222.34 & 924.52 \\
\hline Crystal system & Monoclinic & Triclinic \\
\hline Space group & $\mathrm{C} 2 / \mathrm{c}$ & $\mathrm{P}-1$ \\
\hline$a[\AA]$ & $29.465(2)$ & $7.5193(5)$ \\
\hline$b[\AA]$ & $12.4103(8)$ & $10.7808(6)$ \\
\hline$c[\AA]$ & $14.7059(9)$ & $11.4968(7)$ \\
\hline$\alpha\left[^{\circ}\right]$ & 90.00 & $88.3880(10)$ \\
\hline$\beta\left[^{\circ}\right]$ & $117.727(2)$ & $86.9260(10)$ \\
\hline$\gamma\left[^{\circ}\right]$ & 90.00 & $85.5920(10)$ \\
\hline Volume $\left[\AA^{3}\right]$ & $4760.1(6)$ & $927.61(10)$ \\
\hline $\mathrm{Z}$ & 8 & 1 \\
\hline$D_{c}\left(\mathrm{~g} / \mathrm{cm}^{3}\right)$ & 1.706 & 1.655 \\
\hline $\mathrm{GOF}$ & 1.014 & 1.110 \\
\hline Reflns collected/unique & $4206 / 3233$ & $3611 / 3382$ \\
\hline$R_{\text {int }}$ & 0.0491 & 0.0100 \\
\hline$R 1[\mathrm{I}>2 \sigma(\mathrm{I})]$ & 0.0333 & 0.0291 \\
\hline
\end{tabular}


Table 2. Selected bond lengths ( $⿱$ ) and bond angles (deg) for $\mathbf{1}$ and 2

\begin{tabular}{|c|c|c|c|}
\hline \multicolumn{4}{|c|}{1} \\
\hline Bond & $d, \AA$ & Bond & $d, \AA$ \\
\hline $\mathrm{Zn}(1)-\mathrm{O}(1)$ & $2.079(2)$ & $\mathrm{Zn}(1)-\mathrm{O}(4 \mathrm{~A})$ & $2.125(2)$ \\
\hline $\mathrm{Zn}(1)-\mathrm{O}(5)$ & $1.989(2)$ & $\mathrm{Zn}(1)-\mathrm{N}(2 \mathrm{~A})$ & $2.103(2)$ \\
\hline $\mathrm{Zn}(1)-\mathrm{N}(8)$ & $2.007(3)$ & $\mathrm{Zn}(2)-\mathrm{N}(3)$ & $2.180(3)$ \\
\hline $\mathrm{Zn}(2)-\mathrm{N}(4)$ & $2.085(3)$ & $\mathrm{Zn}(2)-\mathrm{N}(5 \mathrm{~B})$ & $2.063(2)$ \\
\hline $\mathrm{Zn}(2)-\mathrm{N}(6)$ & $2.222(3)$ & $\mathrm{Zn}(2)-\mathrm{N}(7)$ & $2.102(3)$ \\
\hline Angle & $\omega$, deg & Angle & $\omega$, deg \\
\hline $\mathrm{O}(5)-\mathrm{Zn}(1)-\mathrm{N}(8)$ & $115.12(12)$ & $\mathrm{O}(5)-\mathrm{Zn}(1)-\mathrm{O}(1)$ & $91.17(9)$ \\
\hline $\mathrm{N}(8)-\mathrm{Zn}(1)-\mathrm{O}(1)$ & $93.49(10)$ & $\mathrm{O}(5)-\mathrm{Zn}(1)-\mathrm{N}(2 \mathrm{~A})$ & $137.51(12)$ \\
\hline $\mathrm{N}(8)-\mathrm{Zn}(1)-\mathrm{N}(2 \mathrm{~A})$ & $104.72(10)$ & $\mathrm{O}(1)-\mathrm{Zn}(1)-\mathrm{N}(2 \mathrm{~A})$ & $100.89(9)$ \\
\hline $\mathrm{O}(5)-\mathrm{Zn}(1)-\mathrm{O}(4 \mathrm{~A})$ & $84.53(9)$ & $\mathrm{N}(8)-\mathrm{Zn}(1)-\mathrm{O}(4 \mathrm{~A})$ & $95.62(10)$ \\
\hline $\mathrm{O}(1)-\mathrm{Zn}(1)-\mathrm{O}(4 \mathrm{~A})$ & $170.87(10)$ & $\mathrm{N}(2 \mathrm{~A})-\mathrm{Zn}(1)-\mathrm{O}(4 \mathrm{~A})$ & $77.25(9)$ \\
\hline $\mathrm{N}(5 \mathrm{~B})-\mathrm{Zn}(2)-\mathrm{N}(4)$ & $97.81(10)$ & $\mathrm{N}(5 \mathrm{~B})-\mathrm{Zn}(2)-\mathrm{N}(7)$ & $92.80(10)$ \\
\hline $\mathrm{N}(4)-\mathrm{Zn}(2)-\mathrm{N}(7)$ & $169.10(10)$ & $\mathrm{N}(5 \mathrm{~B})-\mathrm{Zn}(2)-\mathrm{N}(3)$ & $170.90(11)$ \\
\hline $\mathrm{N}(4)-\mathrm{Zn}(2)-\mathrm{N}(3)$ & $76.88(10)$ & $\mathrm{N}(7)-\mathrm{Zn}(2)-\mathrm{N}(3)$ & 92.91(10) \\
\hline $\mathrm{N}(5 \mathrm{~B})-\mathrm{Zn}(2)-\mathrm{N}(6)$ & $100.58(11)$ & $\mathrm{N}(4)-\mathrm{Zn}(2)-\mathrm{N}(6)$ & $99.62(10)$ \\
\hline $\mathrm{N}(7)-\mathrm{Zn}(2)-\mathrm{N}(6)$ & $75.86(11)$ & $\mathrm{N}(3)-\mathrm{Zn}(2)-\mathrm{N}(6)$ & $87.69(10)$ \\
\hline \multicolumn{4}{|c|}{2} \\
\hline Bond & $d, \AA$ & Bond & $d, \AA$ \\
\hline $\operatorname{Mn}(1)-\mathrm{N}(2)$ & $2.2264(14)$ & $\mathrm{Mn}(1)-\mathrm{O}(8)$ & $2.2376(13)$ \\
\hline $\operatorname{Mn}(1)-\mathrm{N}(3)$ & $2.2556(14)$ & $\mathrm{Mn}(1)-\mathrm{O}(8 \mathrm{~A})$ & $2.3336(14)$ \\
\hline $\mathrm{Mn}(1)-\mathrm{O}(7)$ & $2.1346(14)$ & $\mathrm{Mn}(1)-\mathrm{O}(9)$ & $2.1469(13)$ \\
\hline Angle & $\omega, \operatorname{deg}$ & Angle & $\omega$, deg \\
\hline $\mathrm{O}(7)-\mathrm{Mn}(1)-\mathrm{O}(9)$ & $89.28(6)$ & $\mathrm{O}(7)-\mathrm{Mn}(1)-\mathrm{O}(8 \mathrm{~A})$ & $168.77(5)$ \\
\hline $\mathrm{O}(7)-\mathrm{Mn}(1)-\mathrm{O}(8)$ & $93.40(5)$ & $\mathrm{O}(8)-\mathrm{Mn}(1)-\mathrm{O}(8 \mathrm{~A})$ & $77.32(5)$ \\
\hline
\end{tabular}




\begin{tabular}{ll|ll}
$\mathrm{O}(7)-\mathrm{Mn}(1)-\mathrm{N}(3)$ & $101.62(6)$ & $\mathrm{O}(9)-\mathrm{Mn}(1)-\mathrm{N}(2)$ & $170.50(6)$ \\
$\mathrm{O}(8)-\mathrm{Mn}(1)-\mathrm{N}(3)$ & $161.72(5)$ & $\mathrm{N}(2)-\mathrm{Mn}(1)-\mathrm{O}(8)$ & $95.09(5)$ \\
$\mathrm{N}(2)-\mathrm{Mn}(1)-\mathrm{O}(8 \mathrm{~A})$ & $94.09(5)$ & $\mathrm{N}(2)-\mathrm{Mn}(1)-\mathrm{N}(3)$ & $73.95(5)$ \\
$\mathrm{O}(7)-\mathrm{Mn}(1)-\mathrm{N}(2)$ & $93.03(5)$ & $\mathrm{O}(9)-\mathrm{Mn}(1)-\mathrm{O}(8 \mathrm{~A})$ & $85.12(5)$ \\
$\mathrm{O}(9)-\mathrm{Mn}(1)-\mathrm{O}(8)$ & $93.97(5)$ & $\mathrm{N}(3)-\mathrm{Mn}(1)-\mathrm{O}(8 \mathrm{~A})$ & $88.71(5)$ \\
$\mathrm{O}(9)-\mathrm{Mn}(1)-\mathrm{N}(3)$ & $96.56(5)$ & & \\
\hline
\end{tabular}

Symmetry codes: 1: A: x, 1-y, z-1/2; B: -x+3/2, -y+1/2, 1-z;

2: A: $-\mathrm{x}-1,-\mathrm{y}+2,-\mathrm{z}$.

\section{Description of the Structure}

X-ray single-crystal diffraction analysis reveals that $\mathbf{1}$ crystallizes in the monoclinic system, space group $C 2 / c$ and features a $2 \mathrm{D}$ network structure. The coordination environment of $\mathrm{Zn}(\mathrm{II})$ in $\mathbf{1}$ is displayed in Fig.1. There are two coordination centers, $\mathrm{Zn}(1)$ and $\mathrm{Zn}(2)$, in the crystal structure. The $\mathrm{Zn}(1)$ ion is five-coordinated by two carboxylate oxygen atoms $(\mathrm{O}(1), \mathrm{O} 4 \mathrm{~A}))$ from two different pzdc ligands, two nitrogen donors $(\mathrm{N}(2 \mathrm{~A})$, $\mathrm{N}(8)$ ) from pzdc and HL ligands and one coordinated water molecule $(\mathrm{O}(5))$. The $\mathrm{Zn}(2)$ ion is also five-coordinated by five nitrogen atoms $(\mathrm{N}(3), \mathrm{N}(4), \mathrm{N}(5 \mathrm{~B}), \mathrm{N}(6), \mathrm{N}(7))$. The $\mathrm{Zn}-\mathrm{O}$ distances fall in the range of $1.989(2)-2.125(2) \AA$, and $\mathrm{Zn}-\mathrm{N}$ bond length fall in the 2.007(3)-2.222(3) $\AA$, which are all in the normal ranges and the coordination angles around $\mathrm{Zn}$ atom are in the range $75.86(11)-170.90(11)^{\circ}$. 


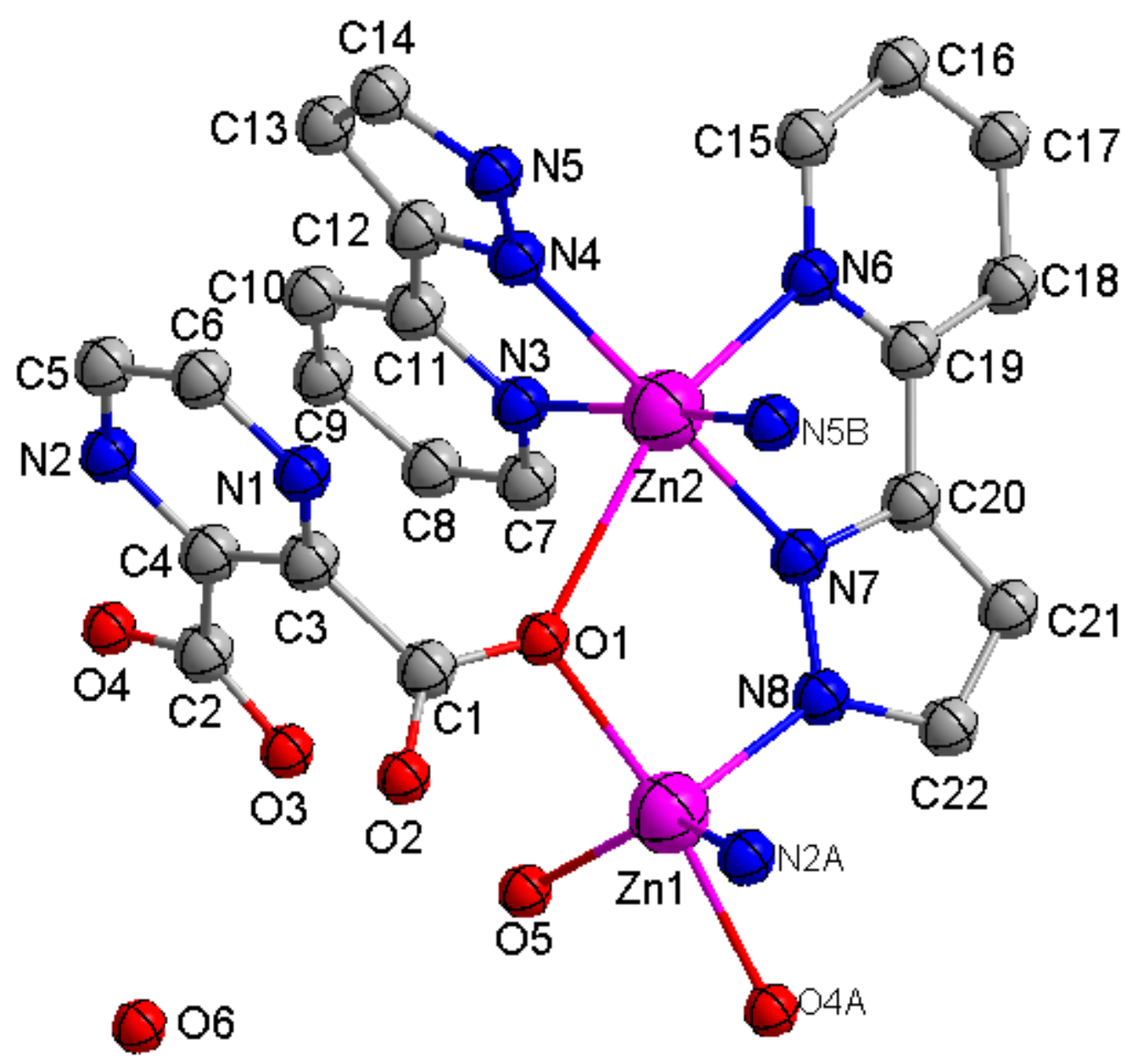

Figure 1. The coordination environment of the $\mathrm{Zn}$ (II) center in 1. Symmetry codes: A: x, 1-y, z-1/2; B: -xt3/2, -yt1/2, 1-z.

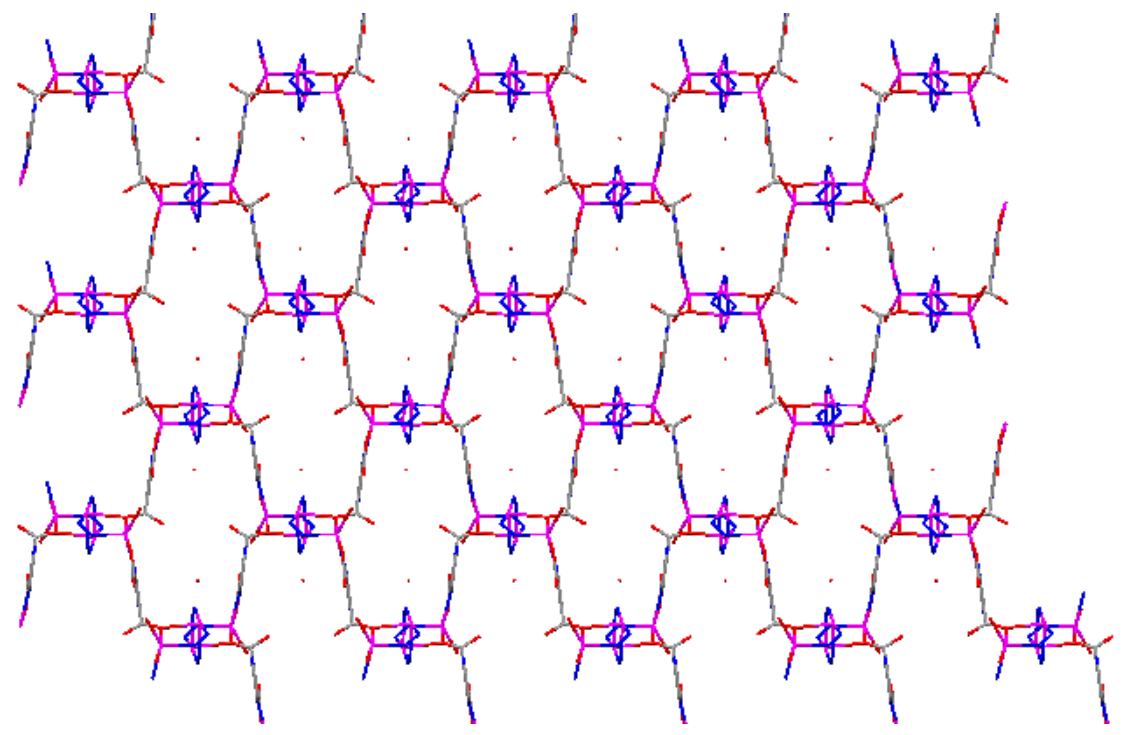


Figure 2. View of the two-dimensional network along a axis (Carbon atoms and one nitrogen atom of HL ligand were ommited for clarity).

In the crystal structure of complex $\mathbf{1}$, the HL ligands take $\mu_{3}$ coordination mode and the completely deprotonated pzdc ligands show one kind of coordination mode, namely, monodentate bridging mode. As a result, two $\mathrm{Zn}$ (II) ions are linked by four HL ligand to form dinuclear subunits, which are bridged by pzdc ligands to yield a two-dimensional (2D) network architecture (Fig.2). Each Zn(II) shows a distorted square-pyramidal coordination structure.

It is worth noting that hydrogen bonding interactions are important in the synthesis of supramolecular architecture. ${ }^{[24]}$ There are existent in $\mathrm{O}-\mathrm{H} \cdots \mathrm{O}$ and $\mathrm{C}-\mathrm{H} \cdots \mathrm{O}$ hydrogen bonding interactions between carboxylate oxygen atom, carbon atoms and coordinated water molecules in complex 1 (Table 3). In addition, there are $\pi$ - $\pi$ interactions (Fig.3) in complex 1 between pyrazine ring of pzdc ligand and pyrazole ring of HL ligand. The centroid-to-centroid distance between adjacent ring is 3.456(2) $\AA$ for $\mathrm{N}(4) \mathrm{N}(5) \mathrm{C}(14) \mathrm{C}(13) \mathrm{C}(12)$ and $\mathrm{N}(1) \mathrm{C}(3) \mathrm{C}(4) \mathrm{N}(2) \mathrm{C}(5) \mathrm{C}(6) \quad(x, y, \quad z)$ rings. The perpendicular distance is $3.1530(15) \quad \AA$ for $\mathrm{N}(4) \mathrm{N}(5) \mathrm{C}(14) \mathrm{C}(13) \mathrm{C}(12)$ and $\mathrm{N}(1) \mathrm{C}(3) \mathrm{C}(4) \mathrm{N}(2) \mathrm{C}(5) \mathrm{C}(6)(x, y, z)$ rings. Thus, the two-dimensional networks are further extended into a three-dimensional supramolecular framework through hydrogen bonds and $\pi$ - $\pi$ interactions, which play an important role in stabilizing compound $\mathbf{1}$. 
Table 3. Hydrogen bonds for complex 1 and $\mathbf{2}$

\begin{tabular}{|c|c|c|c|c|}
\hline $\mathrm{D}-\mathrm{H} \cdots \mathrm{A}$ & $\mathrm{d}(\mathrm{D}-\mathrm{H})$ & $\mathrm{d}(\mathrm{H} \cdots \mathrm{A})$ & $\mathrm{d}(\mathrm{D} \cdots \mathrm{A})$ & $\angle(\mathrm{DHA})$ \\
\hline & & \multicolumn{3}{|l|}{1} \\
\hline $\mathrm{O}(5)-\mathrm{H}(5 \mathrm{~A}) \cdots \mathrm{O}(3)$ & 0.85 & 2.29 & $2.620(4)$ & 103 \\
\hline $\mathrm{O}(5)-\mathrm{H}(5 \mathrm{~B}) \cdots \mathrm{O}(4)$ & 0.85 & 2.09 & $2.823(4)$ & 145 \\
\hline $\mathrm{C}(10)-\mathrm{H}(10) \cdots \mathrm{O}(2)$ & $0.85(4)$ & $2.42(4)$ & $3.248(5)$ & $164(3)$ \\
\hline $\mathrm{C}(17)-\mathrm{H}(17) \cdots \mathrm{O}(2)$ & $0.91(5)$ & $2.58(5)$ & $3.317(6)$ & 139(4) \\
\hline \multicolumn{5}{|c|}{2} \\
\hline $\mathrm{N}(1)-\mathrm{H}(3) \cdots \mathrm{O}(3)$ & $0.98(2)$ & $1.78(2)$ & $2.738(2)$ & $166.6(19)$ \\
\hline $\mathrm{O}(7)-\mathrm{H}(4 \mathrm{~A}) \cdots \mathrm{O}(4)$ & $0.78(3)$ & $1.91(3)$ & 2.6771(19) & $173(2)$ \\
\hline $\mathrm{O}(7)-\mathrm{H}(7 \mathrm{~B}) \cdots \mathrm{O}(1)$ & $0.84(3)$ & $1.86(3)$ & $2.6920(19)$ & 174(3) \\
\hline $\mathrm{O}(8)-\mathrm{H}(8 \mathrm{~A}) \cdots \mathrm{O}(1)$ & $0.64(2)$ & $1.96(2)$ & $2.5962(18)$ & 173(2) \\
\hline $\mathrm{O}(9)-\mathrm{H}(9 \mathrm{~B}) \cdots \mathrm{O}(2)$ & $0.87(3)$ & $1.78(3)$ & $2.6418(19)$ & 169(3) \\
\hline $\mathrm{C}(1)-\mathrm{H}(1 \mathrm{~A}) \cdots \mathrm{O}(2)$ & $0.92(2)$ & $2.46(2)$ & $3.372(2)$ & $169.1(19)$ \\
\hline $\mathrm{C}(5)-\mathrm{H}(5) \cdots \mathrm{O}(5)$ & $1.09(3)$ & $2.35(3)$ & $3.430(3)$ & $171(2)$ \\
\hline $\mathrm{C}(6)-\mathrm{H}(6) \cdots \mathrm{O}(4)$ & $0.96(3)$ & $2.37(3)$ & $3.324(3)$ & 173(3) \\
\hline $\mathrm{C}(7)-\mathrm{H}(7) \cdots \mathrm{O}(6)$ & $0.91(2)$ & $2.53(2)$ & $3.194(3)$ & $130.9(18)$ \\
\hline
\end{tabular}

Complex 2 crystallizes in the triclinic system, space group $P-1$ and features a zero-dimensional structure. The coordination environment of $\mathrm{Mn}(\mathrm{II})$ in $\mathbf{2}$ is displayed in Fig.4. There are two Mn(II) ion, two NIPH ligand, two HL ligand, four coordinated water 
molecule and two $\mu_{2}-\mathrm{O}$ atoms in the molecular structure. Each $\mathrm{Mn}$ (II) ion is six-coordinated by two coordinated water molecules $(\mathrm{O}(7), \mathrm{O}(9))$, two $\mu_{2}-\mathrm{O}$ atoms $(\mathrm{O}(8)$, $\mathrm{O}(8 \mathrm{~A}))$ and two nitrogen donors $(\mathrm{N}(2)$ and $\mathrm{N}(3))$ from HL ligand to supply a distorted octahedral coordination structure. One coordinated water molecule $(\mathrm{O}(9))$, one $\mu_{2}-\mathrm{O}$ atom $(\mathrm{O}(8))$ and two nitrogen atoms $(\mathrm{N}(2), \mathrm{N}(3))$ define an equatorial plane, whereas the axial coordination sites are employed by the other coordinated water molecule $(\mathrm{O}(7))$ and $\mu_{2}-\mathrm{O}$ atom $(\mathrm{O}(8 \mathrm{~A}))$. The $\mathrm{Mn}-\mathrm{O}$ distances fall in the range of 2.1346(14) 2.3336(14) $\AA$, and Mn-N bond length fall in the 2.2264(14) 2.2556(14) $\AA$, which are all in the normal range and the coordination angles around $\mathrm{Mn}(\mathrm{II})$ ion are in the range of $73.95(5)^{\circ} \sim 168.77(5)^{\circ}$

In 2, the HL ligand adopts classic chelating mode, while NIPH ligand was not involved in coordination, which just play a role of balance charge. Two Mn(II) ions are linked by two $\mu_{2}-\mathrm{O}$ atoms to form dinuclear subunits, and exhibits zero-dimensional structure. Further study of the crystal packing of complex 2 suggests that there are three kinds of $\mathrm{N}-\mathrm{H} \cdots \mathrm{O}, \mathrm{O}-\mathrm{H} \cdots \mathrm{O}$ and $\mathrm{C}-\mathrm{H} \cdots \mathrm{O}$ hydrogen bonding interactions between nitrogen atom of HL ligand, carboxylate oxygen atoms of NIPH ligand, coordinated water molecule and carbon atoms of HL and NIPH ligands (Table 3). Moreover, In complex 2, 5-member ring of HL and 6-member ring of NIPH ligand centroid distances are 3.6879(10) $\AA$ for $\mathrm{N}(1) \mathrm{N}(2) \mathrm{C}(3) \mathrm{C}(2) \mathrm{C}(1)$ and $\mathrm{C}(9) \mathrm{C}(10) \mathrm{C}(11) \mathrm{C}(12) \mathrm{C}(13) \mathrm{C}(14)$ rings $(x, y, z)$, with the vertical distance to be $3.2664(7) \AA$, indicating the existence of $\pi$ - $\pi$ effect, so that the structure is more stable. Therefore, a three-dimensional supramolecular network structure is formed by such hydrogen bonds and $\pi$ - $\pi$ stacking (Fig.5). 
In order to check the purity of polymer $\mathbf{1}$ and $\mathbf{2}$, powder X-ray diffraction of the as-synthesized sample were measured at room temperature (Fig.S1). The peak positions of experimental patterns are in good agreement with the simulated ones, which clearly indicates good purity of $\mathbf{1}$ and 2. ${ }^{[25,26]}$

\section{Thermal analysis}

The thermal stability of complex 1 was tested in the range of $50 \sim 700{ }^{\circ} \mathrm{C}$ under a nitrogen atmosphere at a heating rate of $5^{\circ} \mathrm{C} \cdot \mathrm{min}^{-1}$. The TGA curve of complex $\mathbf{1}$ is shown in Fig.S2. It displays that the first weight loss of $49.5 \%$ from 60 to $192{ }^{\circ} \mathrm{C}$ corresponds to the release of water molecules and HL ligand (calcd:50.0\%). Upon further heating, an obvious weight loss $(26.2 \%)$ occurs in the temperature range of $192 \sim 525{ }^{\circ} \mathrm{C}$, corresponding to the removal of pzdc ligands (calcd: $27.1 \%$ ). After $525{ }^{\circ} \mathrm{C}$ no weight loss is found, which indicates the complete decomposition of $\mathbf{1}$.

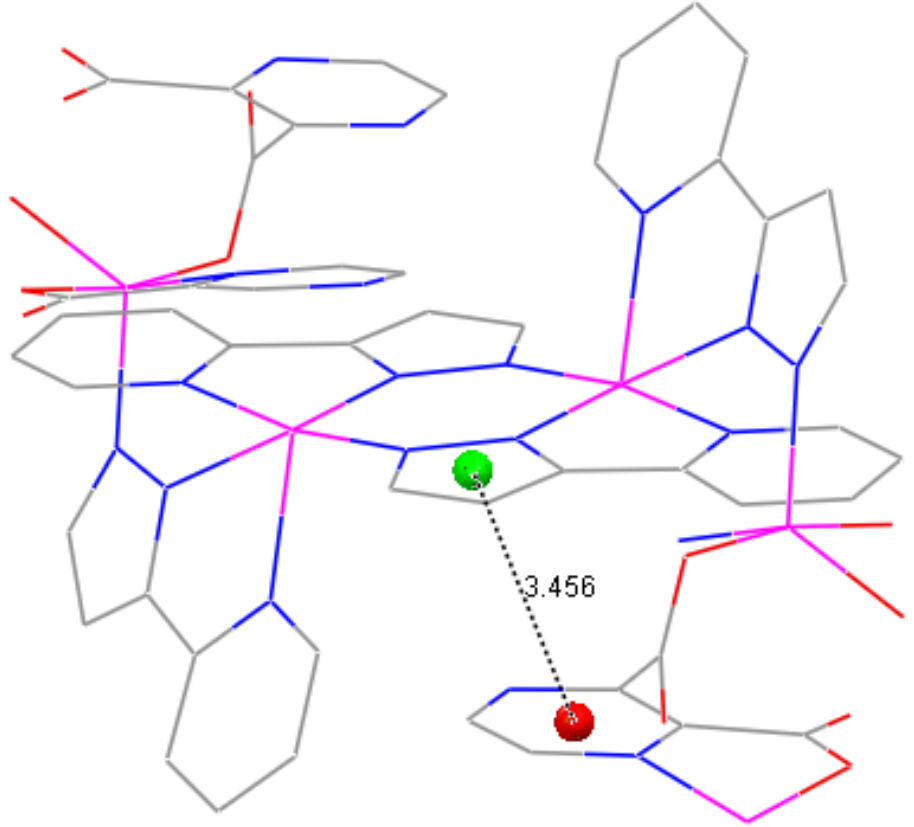

Figure 3. A view of p-p stacking interactions in complex 1. 


\section{Photoluminescent properties}

The emission spectrum of complex $\mathbf{1}$ in the solid state at room temperature is displayed in Fig.6. It can be reviewed that complex 1 shows blue photoluminescence with an emission maximum at $c a$. $460 \mathrm{~nm}$ upon excitation at $375 \mathrm{~nm}$. By way of studying the nature of these emission bands, we first investigated the photoluminescence properties of free pyrazine-2,3-dicarboxylic acid, and indicated that it does not emit any luminescence in the range of $400 \sim 800 \mathrm{~nm}$. And then we discussed the emission spectrum of HL itself and the result confirmed that it does not emit any luminescence in the range $400 \sim 800$ $\mathrm{nm}$, which has also been proved previously. ${ }^{[27]}$ Therefore, on the basis of previous literature, ${ }^{[28]}$ the emission band could be assigned to the emission of ligand-to-metal charge transfer (LMCT). For possessing strong fluorescent intensity, it appears to be good candidates for novel hybrid inorganic-organic photoactive materials.

\section{UV Spectrum Analysis}

The UV spectra for complex 2 (Fig.7), $\mathrm{H}_{2} \mathrm{NIPH}$ and HL ligands have been studied in the solid state. For $\mathrm{H}_{2} \mathrm{NIPH}$ and HL ligands, there are 277 and $245 \mathrm{~nm}$ absorption bands, respectively, while $275 \mathrm{~nm}$ for complex 2 , which should be assigned to the $\mathrm{n} \rightarrow \pi^{*}$ [29-32] transition of HL ligand in 2. However, upon ligand coordination to $\mathrm{Mn}^{2+}$ ion, the absorption intensity increases. 


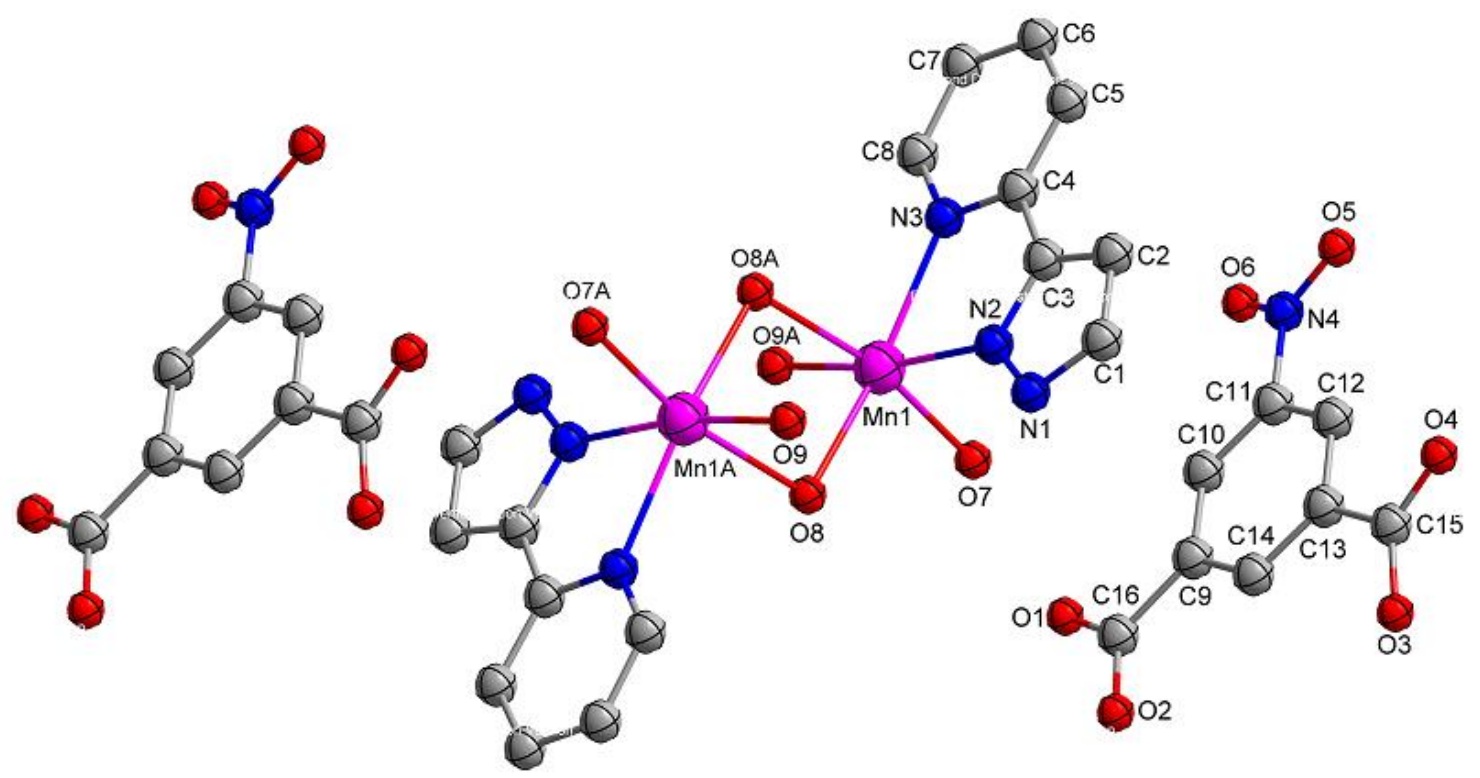

Figure 4. The molecular structure of complex 2. Symmetry codes: A: - x-1, -yt2, -z.

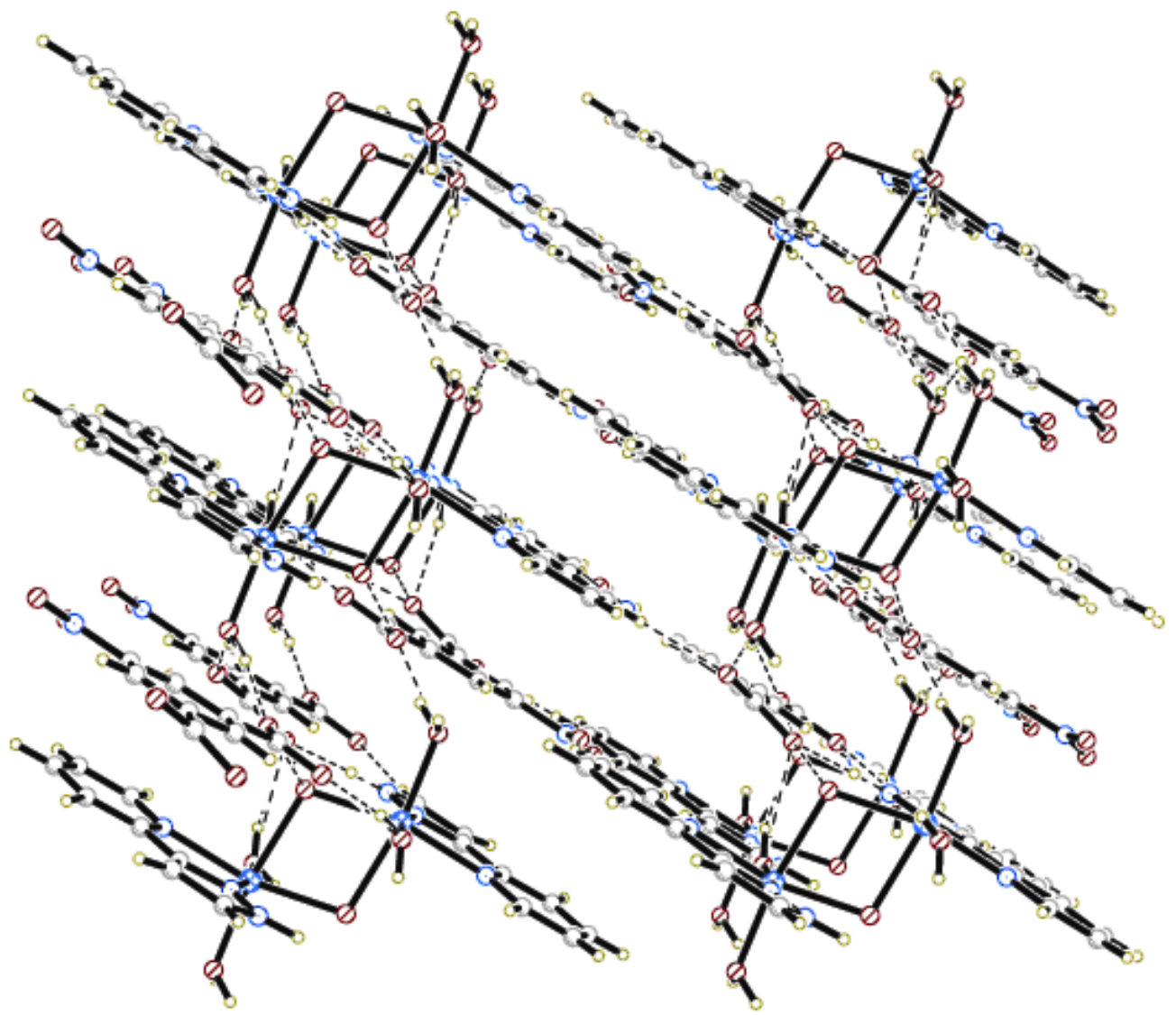

Figure 5. View of the 3D supramolecular architecture of 2 formed by

hydrogen-bonding and p-p interactions. 


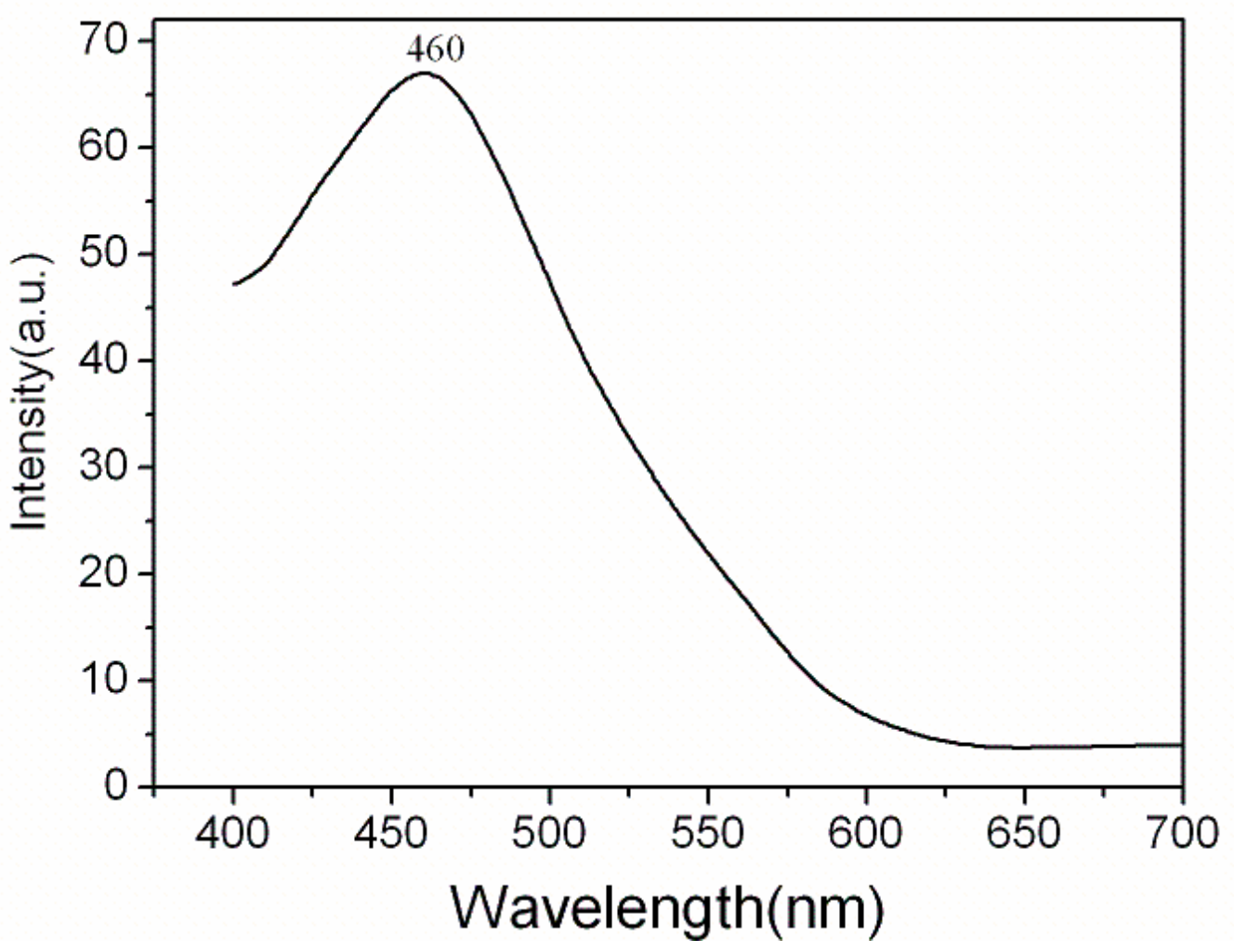

Figure 6. Solid-state emission spectrum of 1 at room temperature.

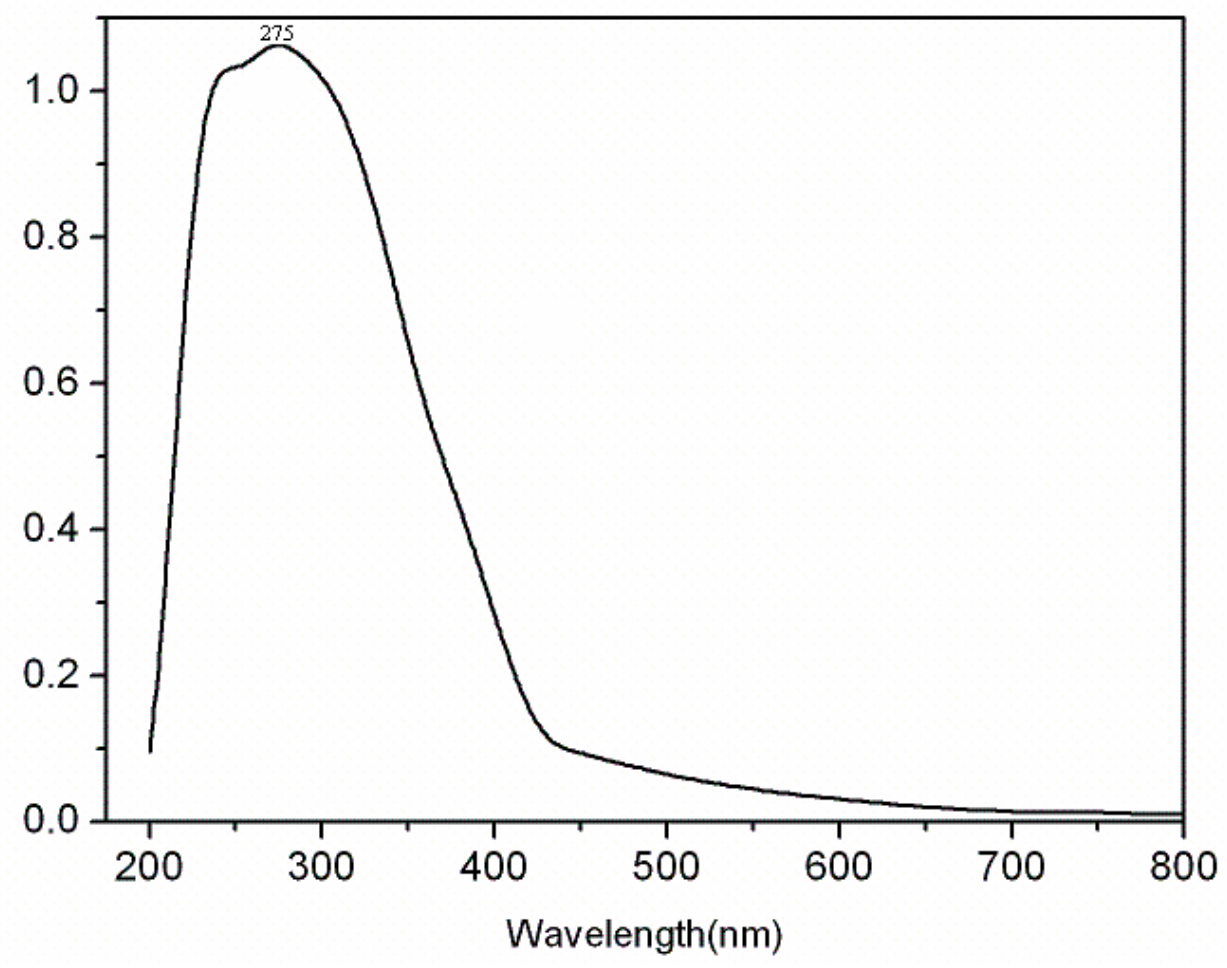

Figure 7. The UV spectrum of 2 at room temperature. 


\section{Conclusions}

In general, we have described two new supramolecular zinc, manganese coordination polymers. In 1, the pyrazine-2,3-dicarboxylate ligands function in monodentate bridging coordination mode, the HL ligands take $\mu_{3}$ coordination mode. As a result, two $\mathrm{Zn}$ (II) ions are linked by four HL ligand to yield dinuclear subunits, which are bridged by pzdc ligands to form a two-dimensional network structure. In 2, the HL ligand takes classic chelating mode, while NIPH ligand was not involved in coordination, which just play a role of balance charge. Two $\mathrm{Mn}$ (II) ions are linked by two $\mu_{2}-\mathrm{O}$ atoms to form dinuclear subunits, and exhibits zero-dimensional structure. It is worthy to note that the intermolecular hydrogen bonds and $\pi-\pi$ interactions play an important role in the supramolecular structure and extended complex 1 and 2 into 3D supramolecular framework.

\section{Acknowledgments}

This work was supported by the Science and Technology Development Project of Jilin Provincial Science \& Technology Department (201205080) and the Science and Technology Research Projects of the Education Department of Jilin Province (2013.384). Program supports from State Key Laboratory of Theoretical and Computational Chemistry of Tonghua Normal University are gratefully acknowledged.

\section{References}

1. Uppadine, L.H.; Lehn, J.M. Three-level synthetic strategy towards mixed-valence and heterometallic [2×2] gridlike arrays. Angew Chem. Int. Ed. 2004, 43, 240-243. 
2. Ruben, M.; Rojo, J.; Romero-Salguero, F.J.; Uppadine, L.H.; Lehn, J.M. Grid-type metal Ion architectures: functional metallosupramolecular arrays. Angew Chem. Int. Ed.2004, 43, 3644-3662.

3. Hou, L.; Li, D.; Shi, W.J.; Yin, Y.G.; Ng, S.W. Ligand-controlled mixed-valence copper rectangular grid-type coordination polymers based on pyridylterpyridine. Inorg. Chem. 2005, 44, 7825-7832.

4. Hines, C.C.; Reichert, W.M.; Griffin, S.T.; Bond, A.H.; Snowwhite, P.E.; Rogers, R.D. Exploring control of cadmium halide coordination polymers via control of cadmium(II) coordination sites utilizing short multidentate ligands. J. Mol. Struct. 2006, 796, 76-85.

5. Wang, X.L.; Qin, C.; Wang, E.B.; Su, Z.M. Metal nuclearity modulated four-, six-, and eight-connected entangled frameworks based on mono-, bi-, and trimetallic cores as nodes. Chem. Eur. J. 2006, 12, 2680-2691.

6. García-Couceiro, U.; Castillo, O.; Luque, A.; García-Terán, J.P.; Beobide, G.; Román, P. Rational design of 2D magnetic metal-organic coordination polymers assembled from oxalato and dipyridyl spacers. Cryst. Growth Des. 2006, 6, $1839-1847$.

7. Hong, M.C. ; Zhao, Y.J.; Su, W.P.; Cao, R.; Fujita, M.; Zhou, Z.Y.; Chan, A.S.C. A silver(I) coordination polymer chain containing nanosized tubes with anionic and solvent molecule guests. Angew. Chem. Int. Ed. 2000, 39, 2468-2470.

8. Hong, M.C.; Zhao, Y.J.; Su, W.P.; Cao, R.; Fujita, M.; Zhou, Z.Y.; Chan, A.S.C. A nanometer-sized metallosupramolecular cube with Oh symmetry. J. Am. Chem. Soc. 2000, $122,4819-4820$. 
9. Abrahams, B.F.; Batten, S.R.; Grannas, M.J.; Hamit, H. ; Hoskins, B.F. ; Robson, R. $\mathrm{Ni}(\mathrm{tpt})\left(\mathrm{NO}_{3}\right)_{2}-\mathrm{a}$ three-dimensional network with the exceptional $(12,3)$ topology: a self-entangled single net. Angew. Chem. Int. Ed. 1999, 38, 1475-1477.

10. Bu, X.H.; Chen, W.; Lu, S.L.; Zhang, R.H.; Liao, D.Z.; Bu, W.M.; Shionoya, M.; Brisse, F.; Ribas, J. Flexible meso-bis(sulfinyl) ligands as building blocks for copper(II) coordination polymers: cavity cntrol by vrying the cain lngth of lgands. Angew. Chem. Int. Ed. 2001, 40, 3201-3203.

11. Noro, S.; Kitaura, R.; Kondo, M.; Kitagawa, S.; Ishii, T.; Matsuzaka, H.; Yamashita, M. Framework engineering by anions and porous functionalities of $\mathrm{Cu}(\mathrm{II}) / 4,4^{6}$-bpy coordination polymers. J. Am. Chem. Soc. 2002, 124, 2568-2583.

12. Bu, X.H.; Chen, W.; Du, M.; Biradha, K.; Wang, W.Z.; Zhang, R.H. Chiral noninterpenetrated (10,3)-a net in the crystal structure of $\mathrm{Ag}(\mathrm{I})$ and bisthioether. Inorg. Chem. 2002, 41, 437-439.

13. Kasai, K.; Aoyagi, M.; Fujita, M. Flexible coordination networks with fluorinated backbones. Remarkable ability for induced-fit enclathration of organic molecules. $J$. Am. Chem. Soc. 2000, 122, 2140-2141.

14. Du, M.; Bu, X.H.; Guo, Y.M.; Ribas, J.; Diaz, C. Proton-controlled inter-conversion between an achiral discrete molecular square and a chiral interpenetrated doublechain architecture. Chem. Commun. 2002, 2550-2551.

15. Li, X.M.; Pan, Y.R.; Ji, J.Y.; Niu, Y.L.; Wang, Q.W. Synthesis, crystal structure and theoretical calculations of a copper(II) coordination polymer assembled by 4,4'-oxydibenzoic acid and 1,4-bis(Imidazol-1-ylmethyl)-benzene ligands. J. Inorg. Organomet Polym. 2014, 24, 836-841. 
16. Pan, Y.R.; Sun, M.; Li, X.M. Hydrothermal syntheses and crystal structures of two complexes of cobalt and manganese assembled by 4,4'-oxydibenzoic acid. Chinese $J$. Struct. Chem. 2015, 34, 576-584.

17. Liu, Y.Y.; Ma, J.F.; Yang, J.; Su, Z.M. Syntheses and characterization of six coordination polymers of zinc(II) and cobalt(II) with 1,3,5-benzenetricarboxylate anion and bis(imidazole) ligands. Inorg. Chem. 2007, 46, 3027-3037.

18. Sheldrick, G.M. SHELXS-97, Programs for X-ray Crystal Structure Solution; University of Göttingen, Germany, 1997.

19. Sheldrick, G.M. SHELXL-97, Programs for X-ray Crystal Structure Refinement; University of Göttingen, Germany, 1997.

20. Devereux, M.; Shea, D.O.; Kellett, A.; McCann, M.; Walsh, M.; Egan, D.; Deegan, C.; Kedziora, E.; Rosair, G.; Müller-Bunz, H. Synthesis, X-ray crystal structures and biomimetic and anticancer activities of novel copper(II)benzoate complexes incorporating 2-(4'-thiazolyl)benzimidazole (thiabendazole), 2-(2-pyridyl) benzimidazole and 1,10-phenanthroline as chelating nitrogen donor ligands. Inorg. Biochem. 2007, 101, 881-892.

21. Farrugia, L.J.; Wing, X.A. Windows Program for Crystal Structure Analysis, University of Glasgow, UK, 1988.

22. Fu, Z.Y.; Wu, X.T.; Dai, J.C.; Hu, S.M.; Du, W.X. The structure and fluorescence properties of two novel mixed-ligand supramolecular frameworks with different structural motifs. Eur. J. Inorg. Chem. 2002, 2002, 2730-2735.

23. Nakamoto, K. Infrared Spectra and Raman Spectra of Inorganic and Coordination Compound, Wiley, New York, 1986. 
24. Krische, M.J.; Lehn, J.M. Struct. Bonding. 2000, 96, 3-29.

25. Gilbert, A.; Baggott, J. Essentials of Molecular Photochemistry, CRC Press, Boca Raton, FL, 1991.

26. Han, Z. B.; He, Y. K.; Ge, C. H.; Ribas, J.; Xu, L. Hydrothermal syntheses, crystal structures and magnetic properties of two copper(II) complexes involved in situ ligand synthesis. Dalton Trans. 2007, 3020-3024.

27. Rendell, D. Fluorescence and Phosphorescence. John Willey \& Sons, New York, 1987.

28. Zheng, S. L.; Chen, X. M. Recent advances in luminescent monomeric, multinuclear, and polymeric $\mathrm{Zn}(\mathrm{II})$ and $\mathrm{Cd}(\mathrm{II})$ coordination complexes. Aust. J. Chem. 2004, 57, $703-712$.

29. Mohamed, G. G.; El-Gamel, N. E. A. Synthesis, investigation and spectroscopic characterization of piroxicam ternary complexes of $\mathrm{Fe}(\mathrm{II}), \mathrm{Fe}(\mathrm{III}), \mathrm{Co}(\mathrm{II}), \mathrm{Ni}(\mathrm{II})$, $\mathrm{Cu}(\mathrm{II})$ and $\mathrm{Zn}$ (II) with glycine and DL-phenylalanine. Spectrochim. Acta, Part A 2004, $60,3141-3154$.

30. Dong, M.M.; He, L.L.; Fan, Y.J.; Zang, S.Q.; Hou, H.W.; Mak, T.C.W. Seven copper coordination polymers based on 5-iodo-isophthalic acid: halogen-related Bonding and N-donor auxiliary ligands modulating effect. Cryst. Growth Des. 2013, 13, $3353-3064$.

31. Glasson, C.R.K.; Meehan, G.V.; Motti, C.A.; Clegg, J.K.; Turner, P.; Jensen, P.; Lindoy, L.F. New nickel(II) and iron(II) helicates and tetrahedra derived from expanded quaterpyridines. Dalton Trans. 2011, 40, 10481-10490.

32. Pandey, S.; Das, P.P.; Singh, A.K.; Mukherjee, R. Cobalt(II), nickel(II) and copper(II) 
complexes of a hexadentate pyridine amide ligand. Effect of donor atom (ethervs. thioether) on coordination geometry, spin-state of cobalt and MIII-MII redox potential. Dalton Trans. 2011, 40, 10758-10768.

\section{Figure captions:}

Fig. 1. The coordination environment of the $\mathrm{Zn}(\mathrm{II})$ center in 1 . Symmetry codes: $\mathrm{A}$ : $\mathrm{x}$, $1-\mathrm{y}, \mathrm{z}-1 / 2 ; \mathrm{B}:-\mathrm{x}+3 / 2,-\mathrm{y}+1 / 2,1-\mathrm{z}$.

Fig. 2. View of the two-dimensional network along $a$ axis (Carbon atoms and one nitrogen atom of HL ligand were ommited for clarity).

Fig. 3. A view of $\pi-\pi$ stacking interactions in complex 1

Fig. 4. The molecular structure of complex 2. Symmetry codes: $A:-x-1,-y+2,-z$.

Fig. 5. View of the 3D supramolecular architecture of 2 formed by hydrogen-bonding and $\pi-\pi$ interactions.

Fig. 6. Solid-state emission spectrum of $\mathbf{1}$ at room temperature

Fig. 7. The UV spectrum of 2 at room temperature

Table 1. Crystallographic parameters and summary of data collection for $\mathbf{1}$ and $\mathbf{2}$

Table 2. Selected bond lengths $(\AA)$ and bond angles (deg) for $\mathbf{1}$ and $\mathbf{2}$

Table 3. Hydrogen bonds for complex 1 and 2 


\section{Supporting information:}
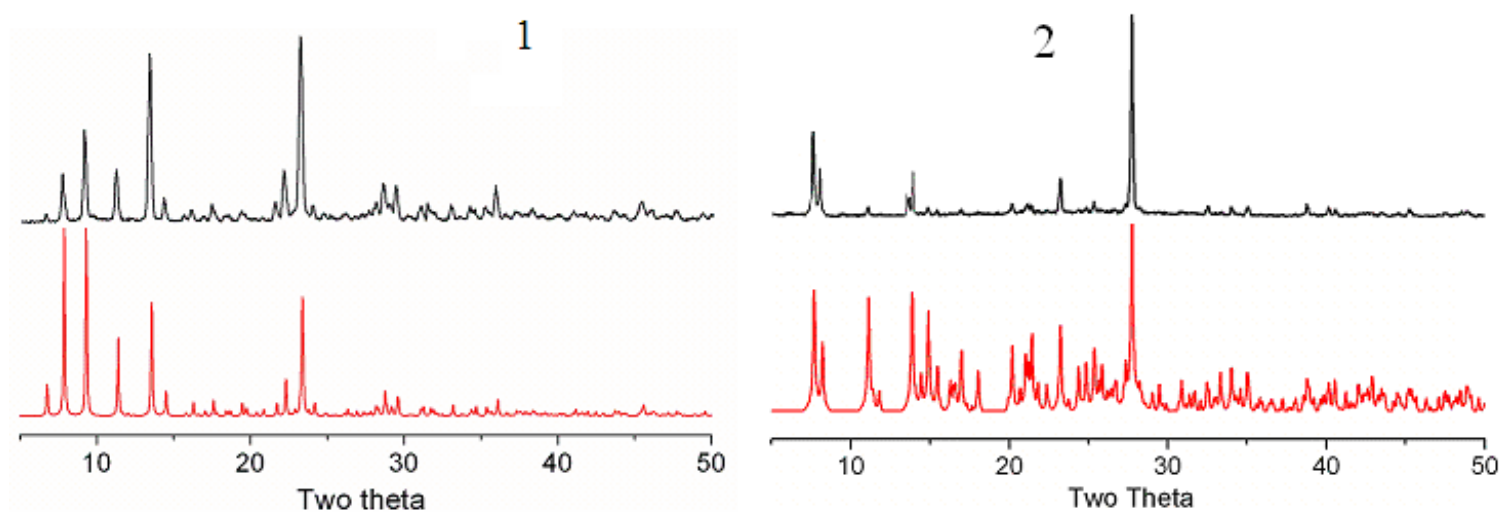

Figure S1. Powder X-ray diffraction of the as-synthesized sample.

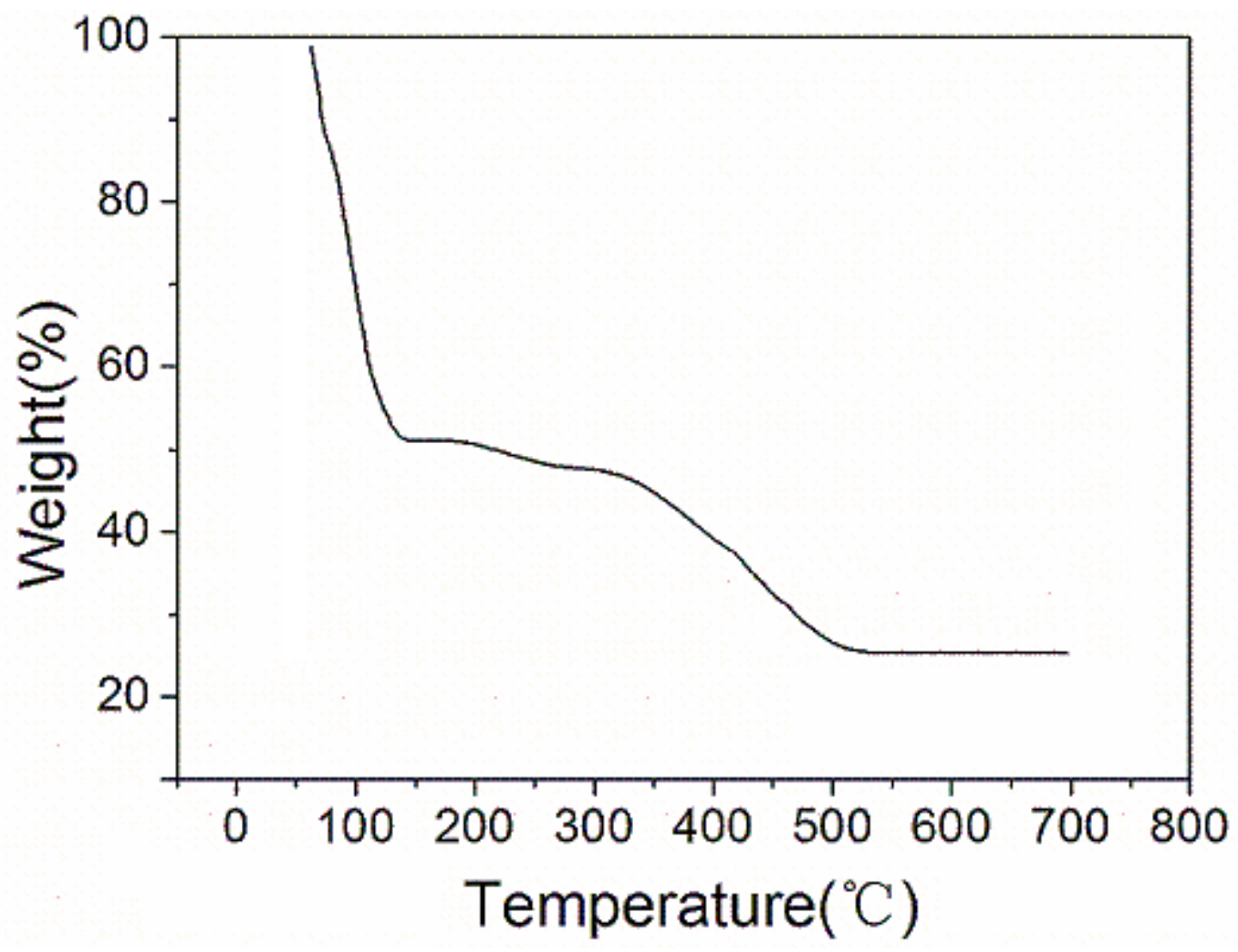

Figure S2. the TGA curve of complex 1. 